\title{
349 生体信号を用いた飲酒・非飲酒状態検知に関する研究
}

The method for drinking detection by biological signals

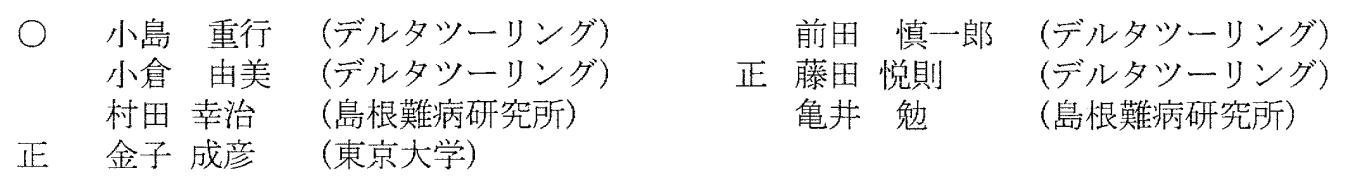

Shigeyuki KOJMA, Delta tooling Co., Ltd., 3-1, Taguchi-Kenkyudanchi, Higashi-hiroshima, Hiroshima Shinichiro MAEDA, Delta tooling Co., Ltd.

Yumi OGURA, Delta tooling Co., Ltd.

Etsunori FUJITA, Delta tooling Co., Ltd.

Kohji MURATA, Shimane Institute of Health Science

Tsutomu KAMEI, Shimane Institute of Health Science

Shigehiko KANEKO, The University of Tokyo

Recently, a system which can monitor a car driver's biological condition and warn the driver of drowsiness is being proposed. Many researchers have presented evidence that biological signals like brain waves, pulsation waves, and cardiac beat, are different between a normal state and a drinking state of a person beforehand. However, current systems to measure those signals are assumed to be used in a laboratory or with invasive monitoring. A basic theory of the system that prevents drunken driving beforehand is constructed by establishing a new algorithm that distinguishes the person's state and ordinary drinking.

Keyword : Sensor, Measurement, Monitoring, Non-aggression Biological Signal, Drink-driving

自動車用シートに着座した人の飲酒の有無を判別できる 非侵襲生体信号センシングシステム付シートを新たに試作 し，このシートを用いた飲酒運転検知のための実験検証を行 った.シートの背部に内蔵された空気圧を利用した生体信号 検出用センサ（以後, エアパックセンサと呼ぶ）を用いて得 られた被験者の飲酒前後における大動脈近傍の脈波（以後, エアパック脈波と㭔ぶ）の原波形老図 Al に示す．飲酒の前 後で比較してエアパック脈波の波形ピークが上昇している のがわかる. 図 A2 はエアパック脈波の加速度脈波から得ら れる飲酒前後の加速度脈波加齢指数（以後, SDPTGAI 亡呼 ぶ）の時系列波形を示す，指尖容積脈波の SDPTGAI 基準 值として, 基準值より高い領域, 基準値近傍の領域, 基準值 より低い領域の 3 つ分けて比較した. 飲酒前後で比較した ところ, 基準值より低い領域で飲酒後に SDPTGAI の増加傾 向が認められた。これはエアパック眽波でのSDPTGAI のカ オス解析あるいは, パターンマッチングによる飲酒検知の可 能性を示唆しているものと考えられる.
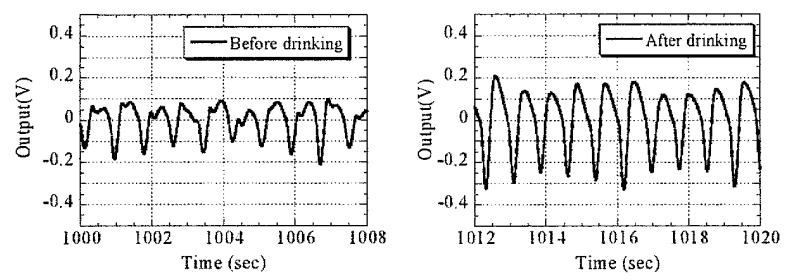

Fig.A1 エアパック脈波原波形 (被験者 A)
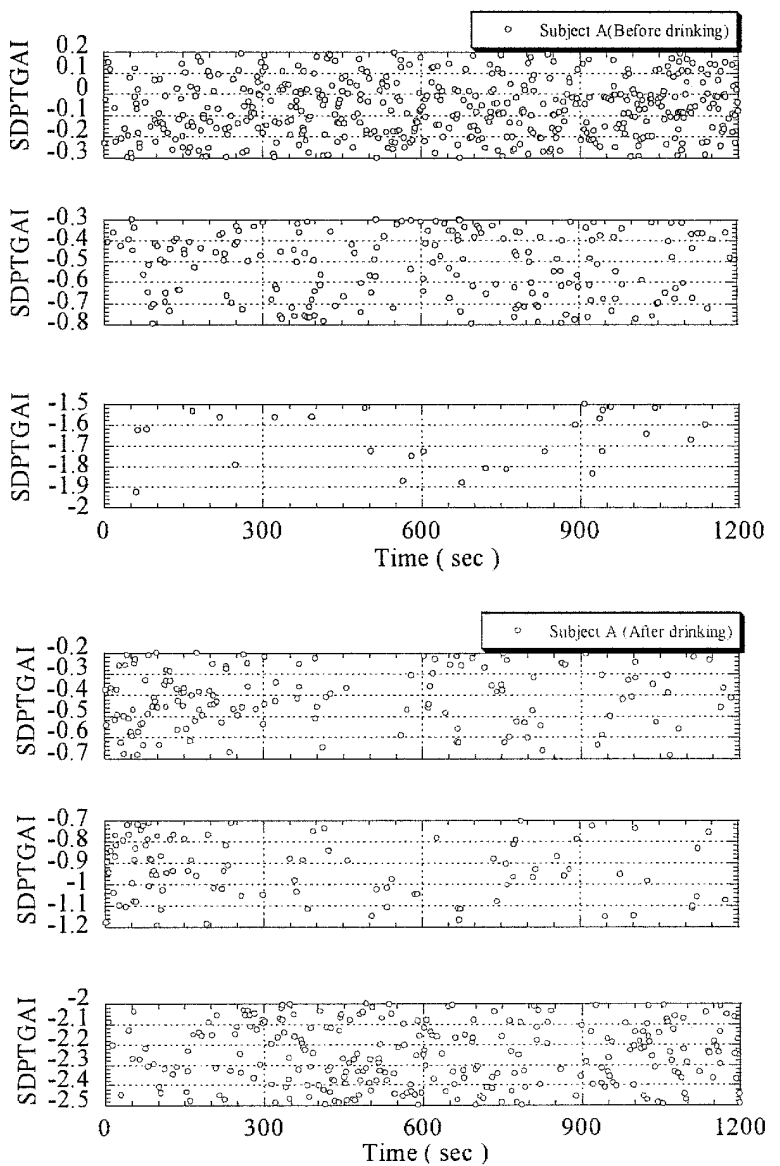

Fig.A2 エアパック脈波 SDPTGAI 比較 (被験者 A) 


\section{1. 緒言}

近年, 飲酒運転による交通事故が社会問題として大きく取 り上げられるようになってきている，国内でも国土交通省が アルコール・インターロック装置の技術課題検討会を開催寸 るなど，アルコール・インターロック装萓の搭載に関する動 きがでてきているが，呼気による飲酒検知装置の場合，装置 の無効化，同乗者の呼気でごまかすといった懸念もあり，他 の有効な検知システムの開発が望まれている.

著者らは既认前報 1)でシートに内藏可能な空気圧を利用し たエアパックセンサを用いた非侵襲の飲酒状態検知の研究 について報告している. 前報では 30 分間の計測によって得 られた脈波の周波数解析を行うことで, 飲酒の有無の判定が 可能であることを示した。しかし，呼気アルコール濃度のよ うな短時間計測での判断は難しく, シートに内蔵されたエア パックセンサが被験者に異物感老与え, 被験者のシートへの 座り心地老悪くする問題もあった。

そこで本研究では, 新たにセンサ内蔵シートを試作し，被 験者の座り心地を向上させ, さらにエアパックセンサの改善 をして，より短い時間での非侵襲での飲酒状態の検知の可能 性について検討を行った.

\section{2. 実験}

\section{$2 \cdot 1$ 実験装置}

図 1 に今回実験に用いたシートと実験風景を示寸.エアパ ックセンサの内部は, ばね部材として 3 次元立体編物が挿入 されている，エアパックセンサは被験者の筋肉との間で内・ 外圧の差を等しくして，圧力変動を捉えるものである．その ため, エアパックのばね特性は人間の筋肉に近似したば称 性を付与している. またシートは, 生体信号を非侵襲で採取 できる3 次元立体編物を用いた張力構造体で構成されるシー 卜を使用した。

また比較用の生体信号として，指尖容積脈波（株式会社了 ムコ製フィンガークリッププローブ SR-5C)，心電計（日本 光電工業株式会社製心電計 ECG-9122)，呼気アルコール濃度 （東海電子株式会社製 ALC-mini）の計測も行った。
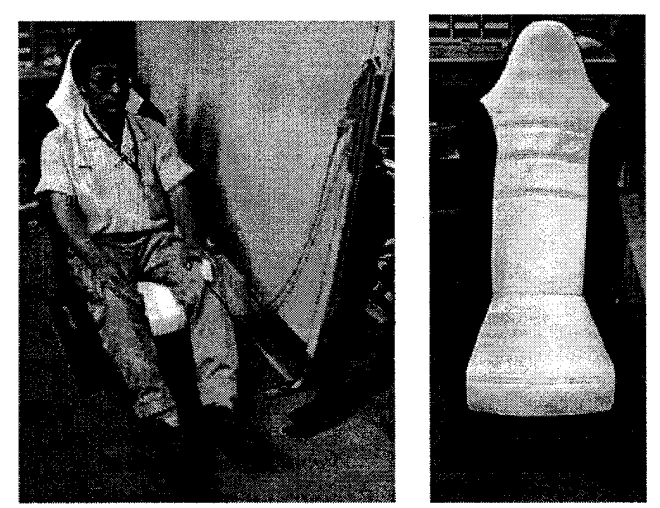

Fig.1 Experimental apparatus

\section{$2 \cdot 2$ 実験方法}

健康な 20 40 歳の成人男性 3 名を被験者として実験を行 った．被験者には，あらかじめ飲酒実験とは別の日にエ夕， 一ルパッチテストを行い，3 名とも活性型（NN 型）である ことを確認した。尚, 被験者の体重および身長は, $\mathrm{A} か ゙$ 体重 $68 \mathrm{~kg}$ 身長 $178 \mathrm{~cm}$, B が $65 \mathrm{~kg}$ 身長 $171 \mathrm{~cm}, \mathrm{C}$ が $58 \mathrm{~kg}$ 身長 $166 \mathrm{~cm}$ の被験者である. 非侵襲センサであるエアパックセンサと比 較用センサによる生体信号の計測は, 飲酒前に 20 分間の計 測を 1 回行い, その後, 飲酒（ビール：アルコール濃度 $5 \%$ ： $500 \mathrm{ml}$ ）をして，飲酒後に最も血液中のアルコール濃度が高 くなるとされている20-40分後の 20 分間に飲酒後の計測を行 った。 また，図 2 に飲酒前と飲酒後の生体信号計測の前後 で，呼気アルコール濃度の測定を行った結果を示す。

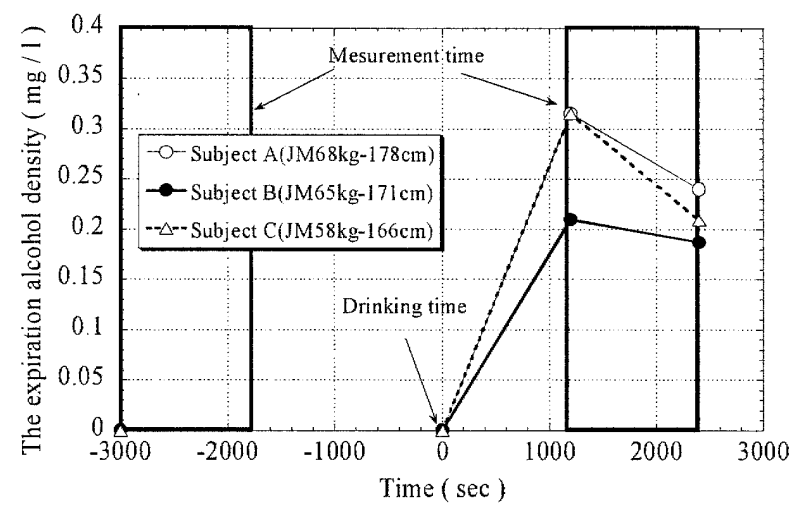

Fig. 2 呼気アルコール濃度

\section{3. 実験結果と考察}

図 3，4 亿被験者 $\mathrm{A}$ の場合の指尖容積脈波とエアパック脈 波の原波形とその1 次微分波形, 2 次微分波形を示寸.また， 図 5,6 亿被験者 $\mathrm{B}$ の場合の指尖容積脈波とエアパック脈波 の原波形と 1 次微分波形, 2 次微分波形を, 図 7,8 亿被験者 Cの場合の指尖容積脈波とエアパック脈波の原波形と 1 次微 分波形, 2 次微分波形を示寸. 指尖容積脈波とエアパック脈 波の原波形を比較すると，若干波形の形状が異なるが，ほぼ 同一の周波数となっていることがわかる.また，指尖容積脈 波では飲酒の前後でそれほど大きな変化が見られないが，エ アパック脈波では飭酒によって脈波の波形ピークが上昇し ているのがわかる、特に飲酒による呼気アルコール濃度の上 昇の大きかった被験者 $\mathrm{A}, \mathrm{C}$ では䫓著にその傾向が見られる. これは指尖容積脈波が末梢系であるため, 他の外部刺激の影 響も受けることにより，指尖容積脈波では飲酒の影響が見え にくくなっているためと考えられる。一方，エアパック脈波 は大動脈近傍の体幹の脈波であると考えられ，外部刺激の影 響は受けにくく，飲酒による血管への影響のみが大きく現れ たためであると考えられる.

次に指尖容積脈波とエアパック脈波の 1 次微分・2次微分 波形を比較してみると，微分により指尖容積脈波とエアパッ 

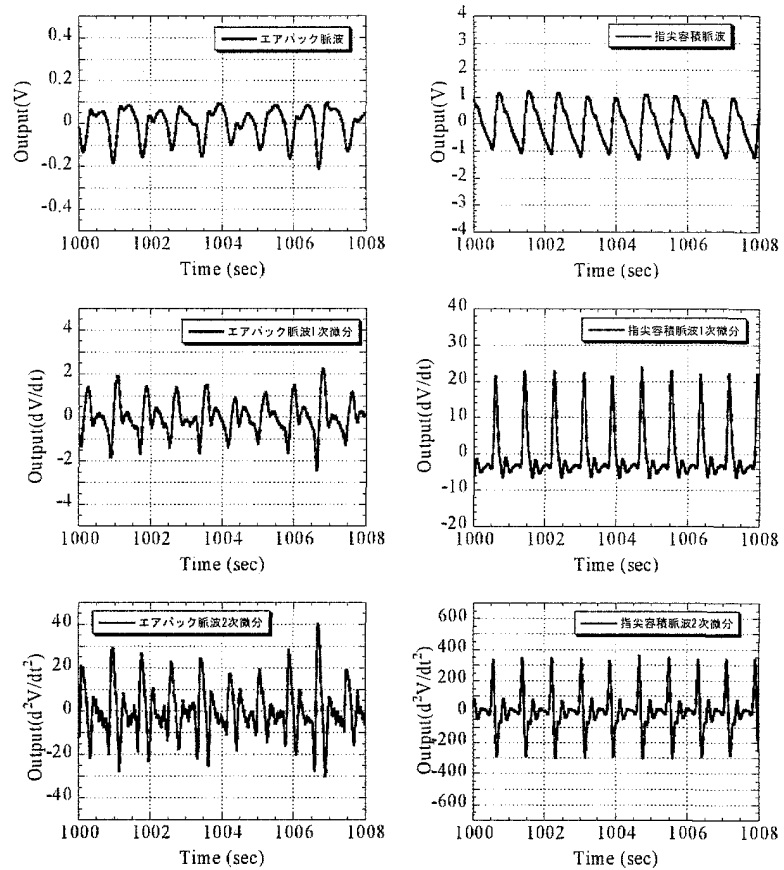

Fig. 3 脈波原波形・微分波形

(被験者 $\mathrm{A} \cdot$ 飲酒前)
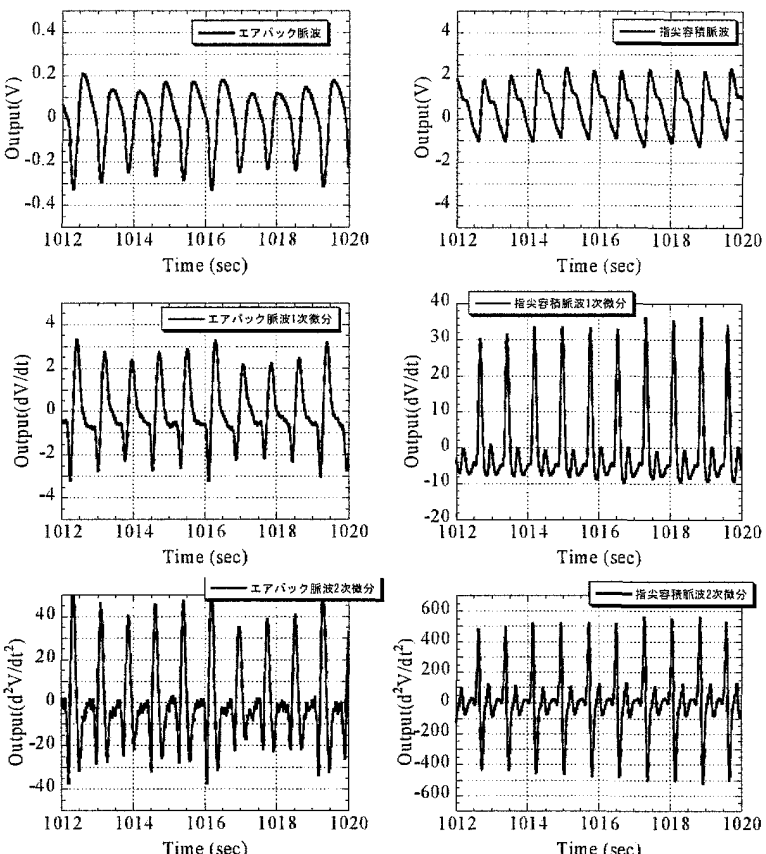

Fig. 4 脈波原波形・微分波形

(被験者 $\mathrm{A} \cdot$ 飲酒後)

ク脈波双方に類似したピークが現れていることがわかる. 特 にエアパック脈波の方が, 顥著にこのピークが現れている. これは一般に動脈圧波形では，心臓の収縮期，拡張期の切り 替わりの近傍で切痕が生じる。この切痕の状態から血管壁の 硬化度合いなどを知ることが出来るが，脈波の 2 次微分波形 である加速度脈波を用いて切痕をより明確に捉え，血管年齢 の推定が出来ることが知られている ${ }^{2)}$.したがって，この切 痕は心臓の収縮期, 拡張期の影響を現していると考えられ， 心臟に近い大動脈波を捉えていると考えられるエアパック
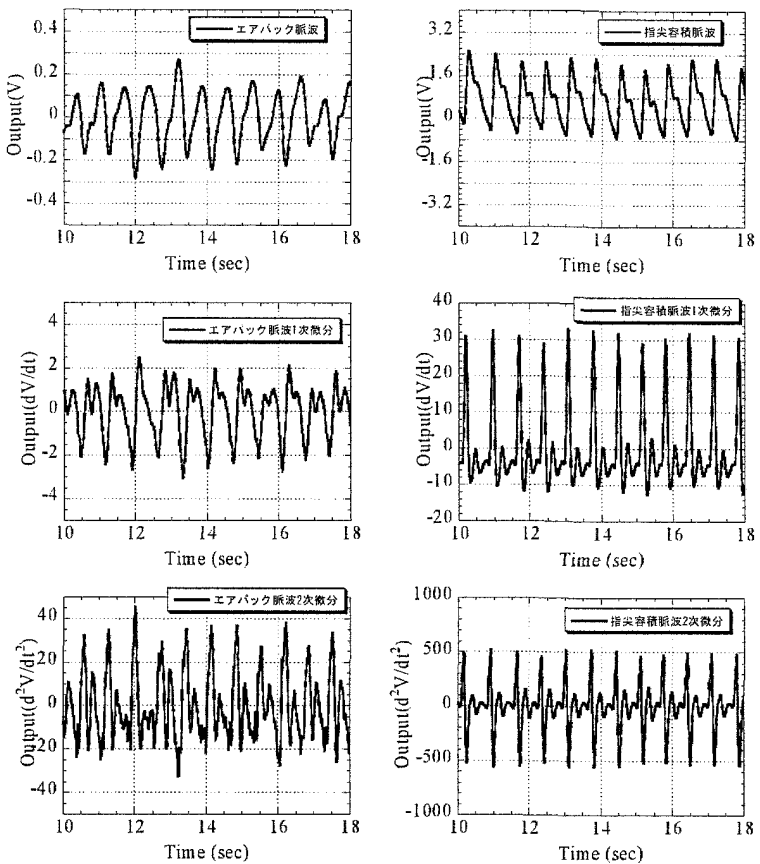

Fig. 5 脈波原波形・微分波形 (被験者 $\mathrm{B} \cdot$ 飲酒前)
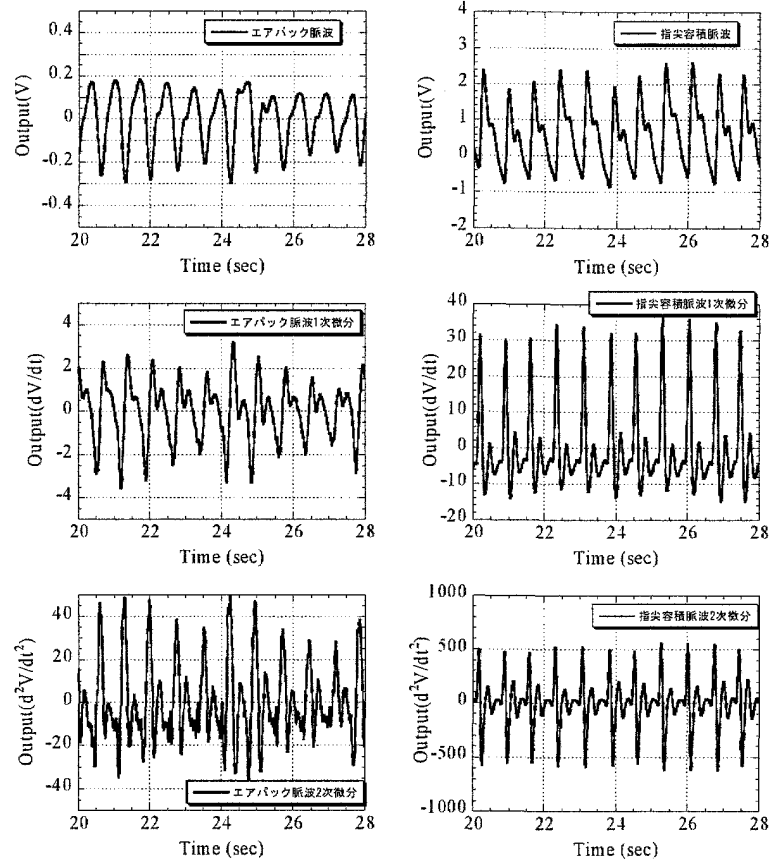

Fig. 6 脈波原波形・微分波形

(被験者 $\mathrm{B} \cdot$ 飲酒後)

脈波の方が切痕の影響による微分波形のピークが强く出て いるためと考えられる。また，一回の心臟の収縮・拡張によ り生じる切痕の影響を受けた 2 次微分波形ピークの一群は, 飲酒の影響によって, 右上がりの傾向を示している. 加速度 脈波においては，血管壁が柔らかくなった場合と同じ傾向で あるが，エ夕ノールの薬理学的影響から血管の拉張が生じる ことが知られており，このような現象が起きたと考えられる。

図9は指尖容積脈波とエアパック脈波の被験者毎の飲酒前 後における原波形周波数解析結果を示寸. 指尖容積脈波と工 
アパック脈波を比較すると飲酒有無に倸わらず，3名の被験 者全員ほぼ同一の周波数特性の傾向を示し，エアパックセン サが血行動態を捉え，脈波をうまく採取出来ていることがわ かる。また, 被験者 $\mathrm{A}, \mathrm{C}$ 浪飲酒により, 脈波が高周波数带 にシフトしていることがわかった。これは前報 ${ }^{1)}$ の指尖容積 眽波での結果と同様であり，飲酒の影響であると考えられる. しかし，被験者 Bにおいては飲酒の前後で，周波数帯がほと んよ゙変化していない，被験者 Bは，3名の中では呼気アルコ 一ル濃度もそれほど，上がっておらず，他の2名と比較して
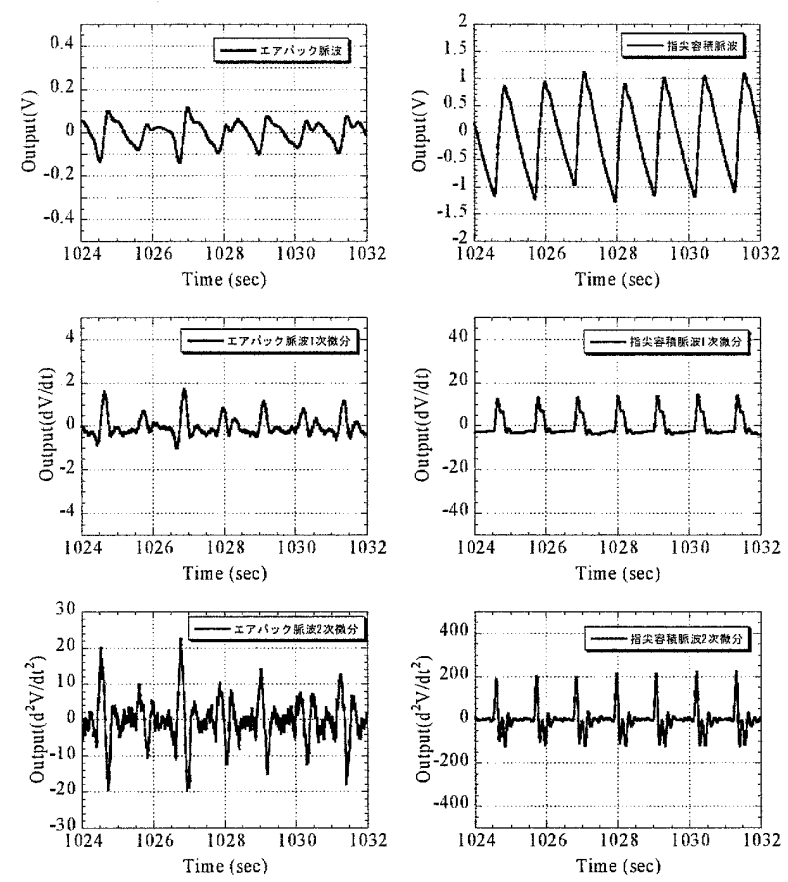

Fig. 7 脈波原波形・微分波形

(被験者 $\mathrm{C} \cdot$ 飲酒前)
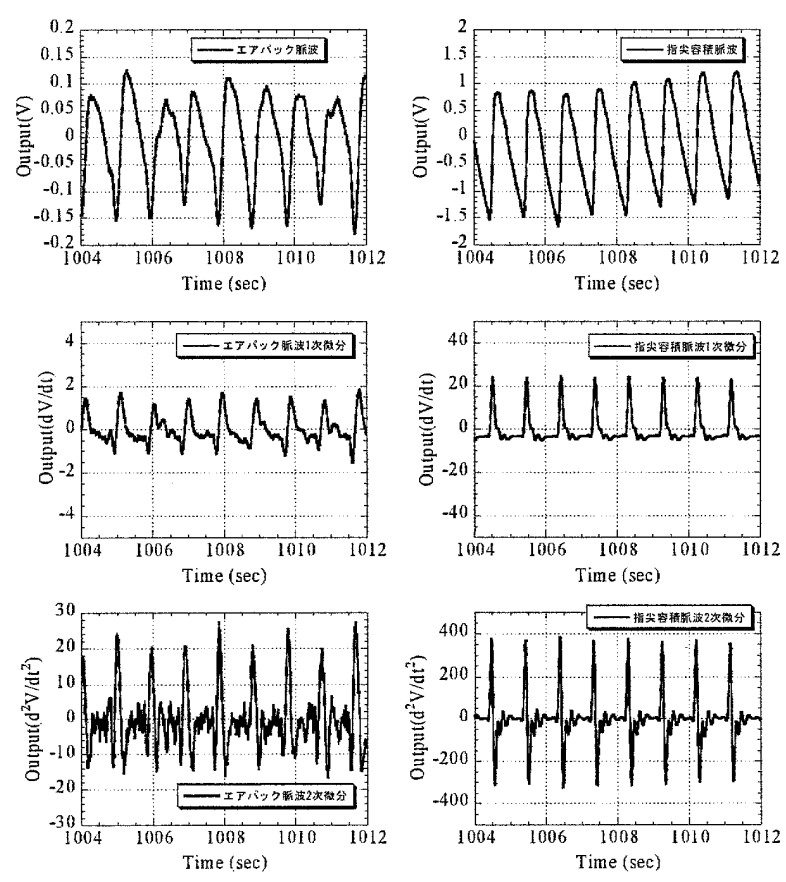

Fig. 8 脈波原波形・微分波形 (被験者 $\mathrm{C} \cdot$ 飲酒後)
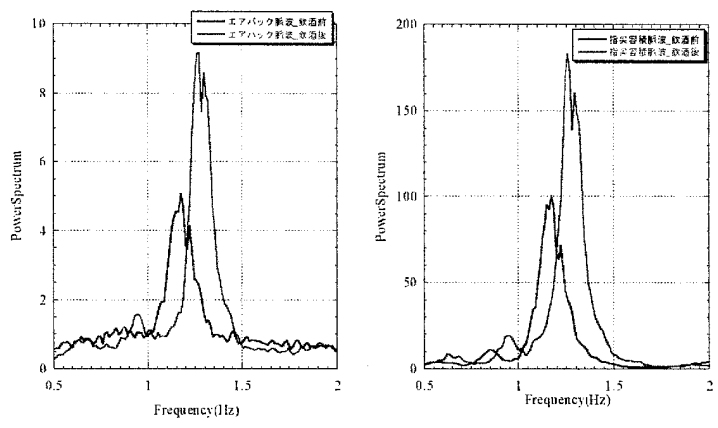

（a）被験者 $\mathrm{A}$
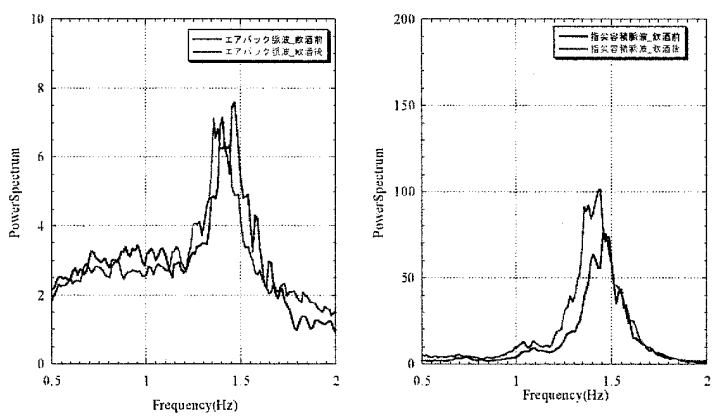

(b)被験者 B
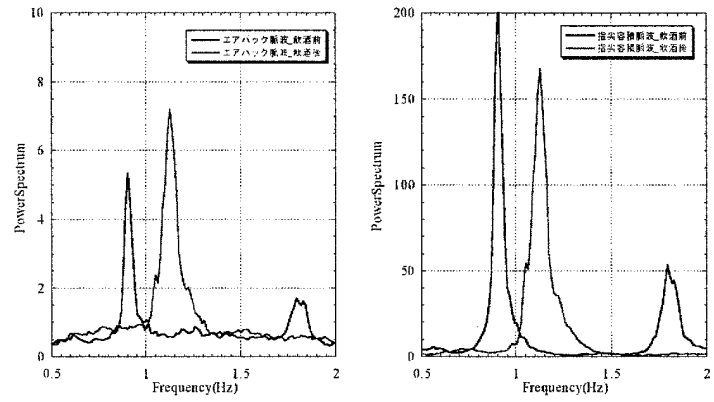

(c) 被験者 $\mathrm{C}$

Fig. 9 脈波原波形周波数解析
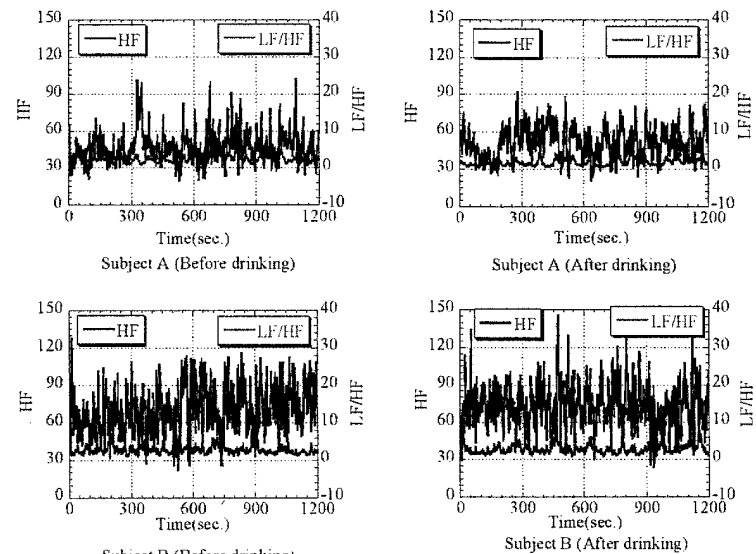

Subject B (Before drinking)
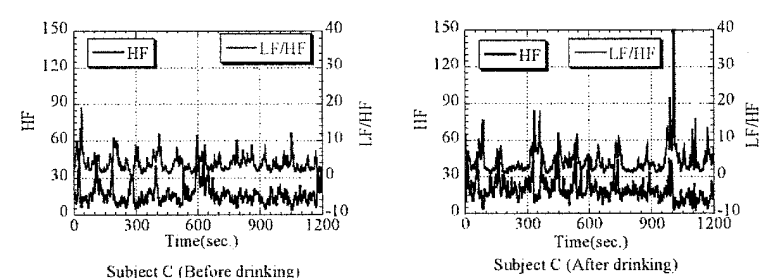

Fig. 10 心拍変動ウェーブレット解析 
も酒に強く，若い被験者であるため，アルコールの影響があ まり出ていないためであると考えられる，図 10 は，心電図 により得られた心拍数変動のウェーブレット解析結果を示 す. また図 11 には指尖容積脈波から得られた心拍数変動の ウェーブレット解析結果を示し, 図 12 はエアパック脈波か ら得られた心拍数変動のウェーブレット解析結果を示す。一 般に HF $(0.15-0.4 \mathrm{~Hz})$ は，副交感神経の心拍への影響を表し， LF/HF(LH は 0.04-0.15Hz) は交感神経の心拍への影響を表す. 図 10 と 11 を比較すると LF/HFがほぼ同じ位置のピークを出 しているが，飲酒前後で大きな差が見られない。しかしなが ら，図12に示したエアパック脈波では，飲酒後に自律神経
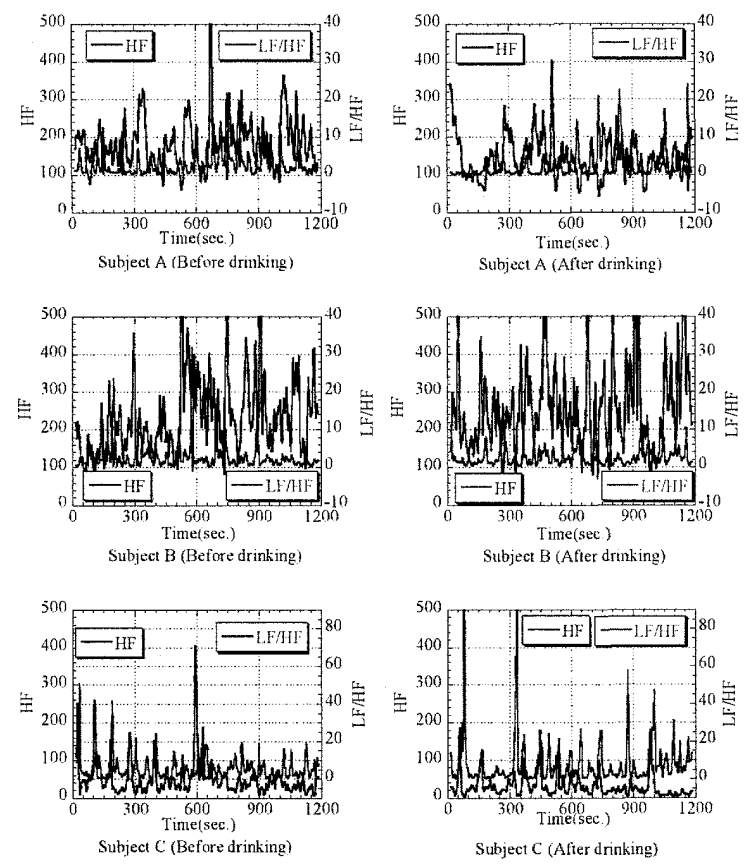

Fig. 11 指尖容積脈波ウェーブレット解析
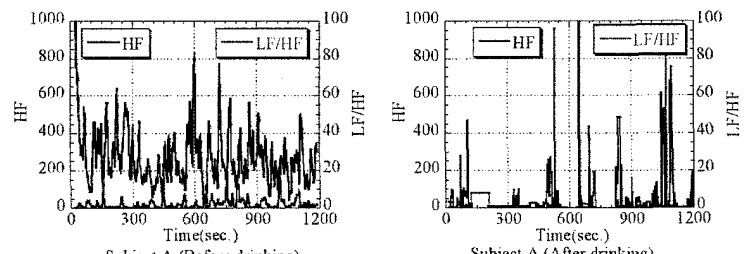

Subject A (Affer drinking)
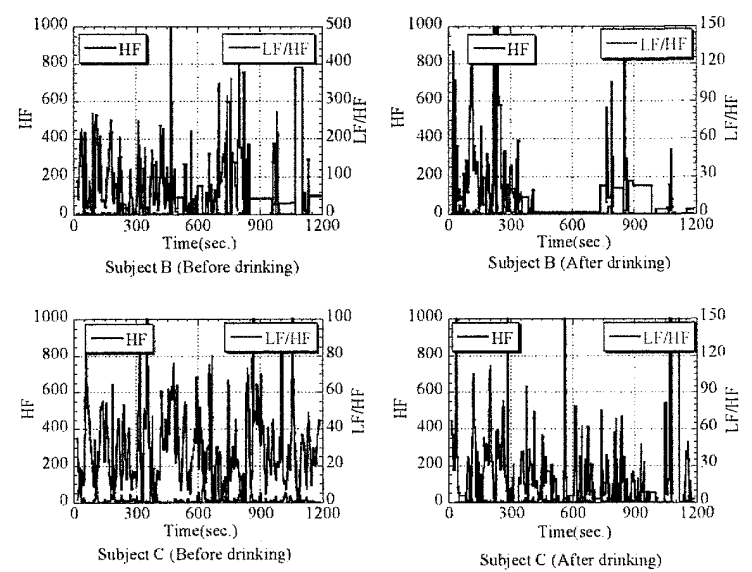

Fig. 12 エアパック脈波ウェーブレット解析
矛の活動がうまく捉えられていない。これは飲酒による血管 のみの影響が大きく現れたことを示し，体幹の脈波であるエ アパック脈波の原波形に飲酒による影響が生じたものと考 えられる。

図 13 法指尜容積脈波とエアパック脈波の加速度脈波から 得られる飲酒前後の各被騟者のSDPTGAI ${ }^{2}$ の時系列波形を 示す. SDPTGAI は血管年齢の推定に用いられる指標である が，長年の生活習慣病から来る血管壁の動脈硬化による影響 だけでなく，血管内圧の上昇といった一時的な外部刺激など による影響も受ける指標であることが知られている。この事 実を逆に利用して，加図 12 の結果から飲酒の有無の変化 が捉えられるのではないかと考え, 今回の実験デー夕から検 討を行った。図 13 に示した指尖容積脈波から得られた SDPTGAIは，飲酒によって低下していることがわかる，脈 波原波形の周波数解析や心拍変動のウェーブレット解析で は，飲酒の判別の困難であった被験者 B でも飲酒による SDPTGAIの低下が確認されており, 飲酒の判別に有効な指 標となる可能性があることがわかった。一方，エアパック脈 波から得られたSDPTGAI では, 被験者 A, Cの場合, 指尖 容積脈波の場合と同様に飲酒時に低下傾向が見られるが，被 験者 B の場合, 単純な比較では飲酒の有無の判別が難しいこ とがわかる。 そこで図 14，15，16 に示すように指尖容積脈 波の SDPTGAI 基準值として, エアパック脈波の SDPTGAI を基準值より高い領域，基準值近傍の領域，基準值より低い 領域の 3 つに分けて飲酒前後で比較した. その結果, 被験者 3 名とも基準值より低い領域で SDPTGAIの増加㑯向が認め られた。これは，エアパック脈波によるSDPTGAIのパター ンマッチングによる飲酒検知の可能性を示唆しているもの
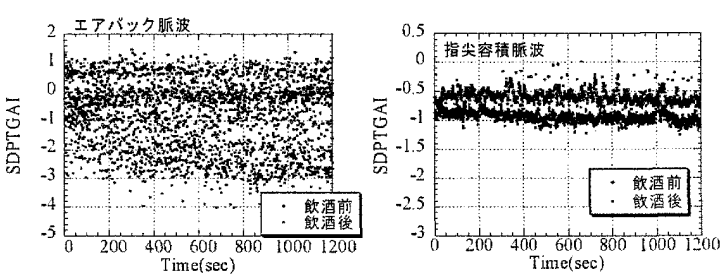

(a) 被験者 $\mathrm{A}$
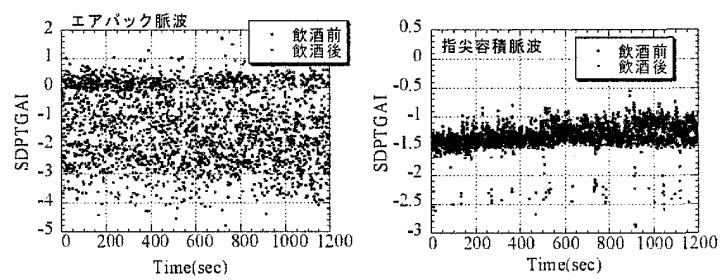

(b) 被験者 $\mathrm{B}$
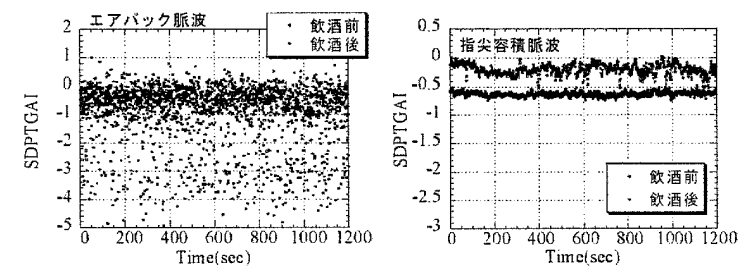

（c）被験者 $\mathrm{C}$

Fig. 13 SDPTGAI 比較 

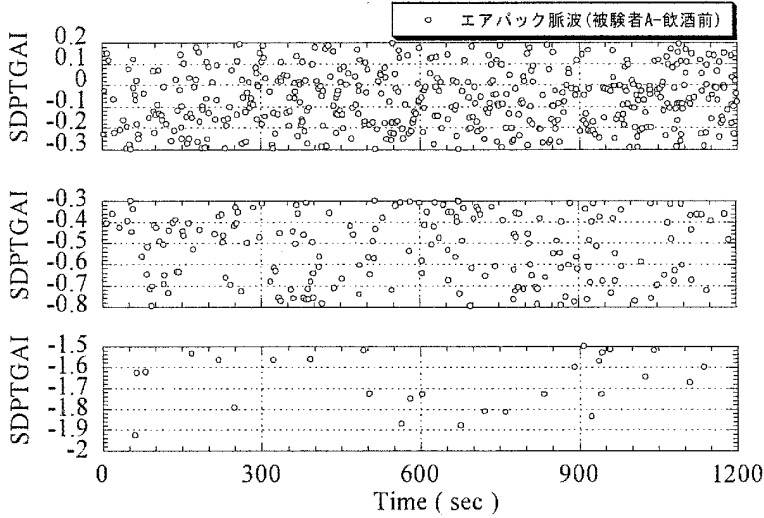

(a)被験者 $A$, 飲酒前
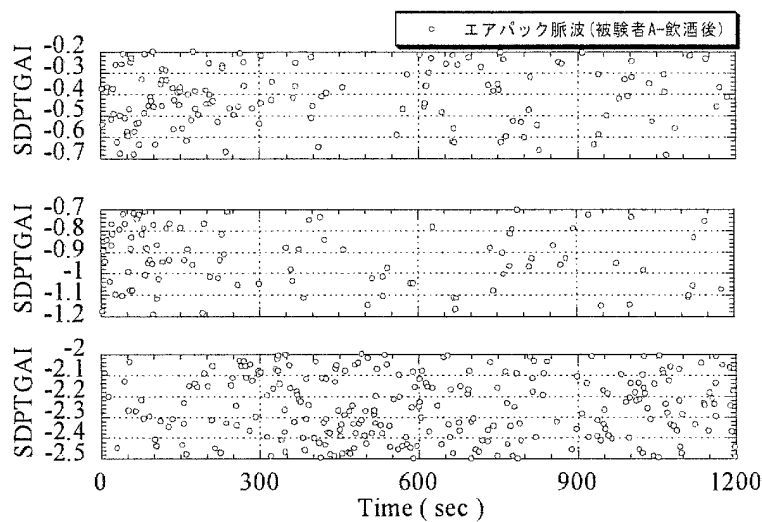

(b)被験者 $\mathrm{A}$, 飲酒後

Fig. 14 エアパック脈波 SDPTGAI 比較 (被験者 A)
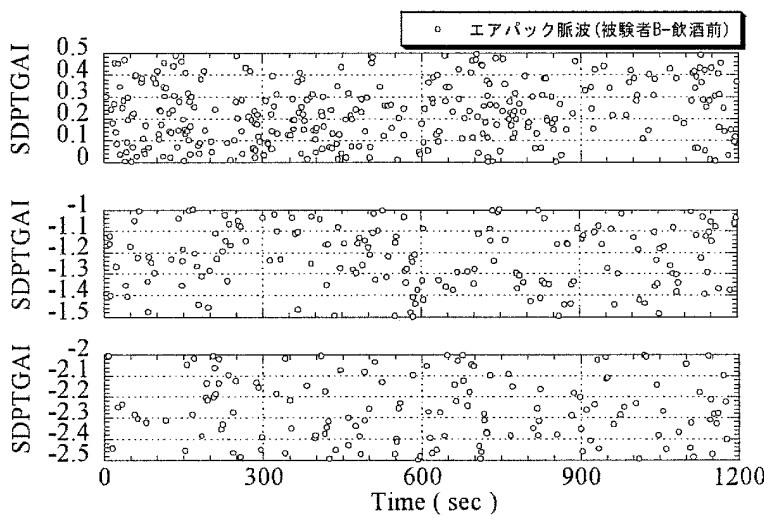

(a)被験者 $\mathrm{B}$ ，飲酒前
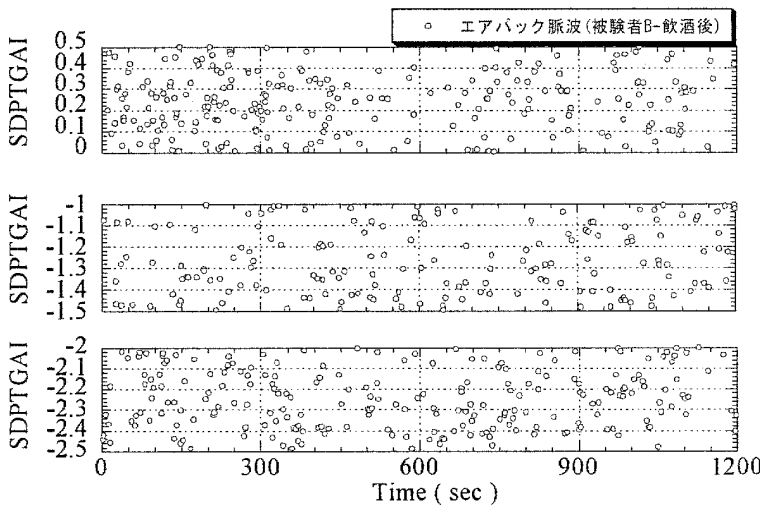

(b)被験者 $\mathrm{B}$, 飲酒後

Fig. 15 エアパック脈波 SDPTGAI 比較 (被験者 B)
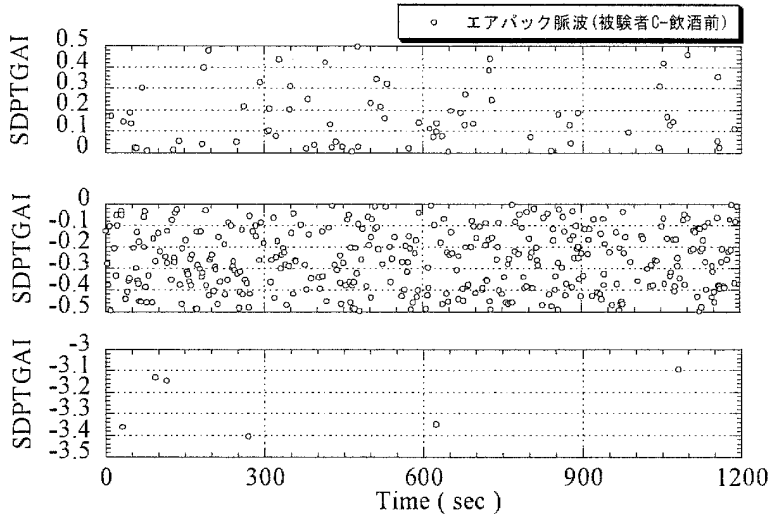

(a)被験者 $\mathrm{C}$ ，飲酒前
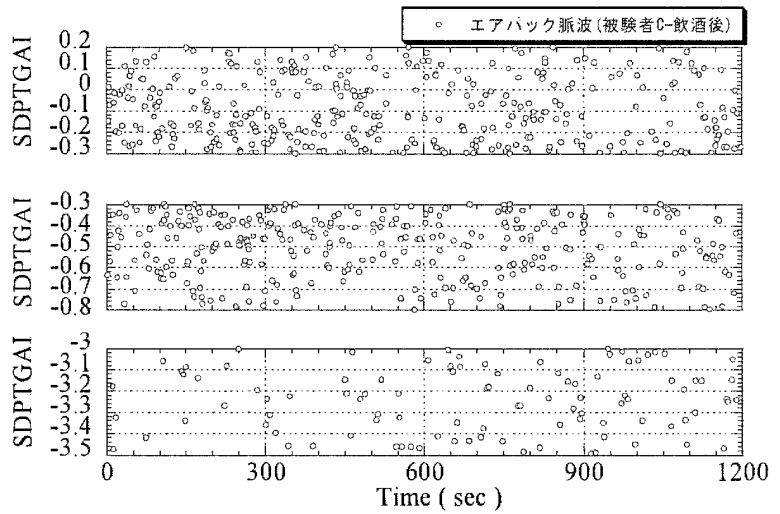

(b)被験者 $\mathrm{C}$, 飲酒後

Fig. 16 エアパック脈波 SDPTGAI 比較 (被験者 C)

と考えられる.また変化の少ない指尖容積脈波の SDPTGAI を基準にしてェアパック脈波の SDPTGAI の桩散状況を捉え ることで飲酒の有無を判断できる可能性が示唆された。

\section{4. まとめ}

自動車用シートに内蔵されたエアパックセンサを用いて， 大動脈近傍の脈波を捉えることが可能であることを示し，こ の脈波は指尖容積脈波に近い周波数特性を持ち, 飲酒によっ て脈波の原波形のピーク值が上昇していることがわかった。 また指尖容積脈波のSDPTGAI を基準にしたエアパック脈波 のSDPTGAI の抬散状況のパターンマッチングにより, 比較 的短時間の計测により，エアパックセンサによる飲酒検知の 可能性が示唆された.

今回得られた結果から考えて飲酒時のSDPTGAI はカオス 性を有しているのではないかと考えられ，今後はSDPTGAI のカオス解析を行い, より精度の高い飲酒検知センシングシ ステムの構築を検討していく予定である.

\section{参考文献}

（1）小島重行, 我田茂樹, 落合直輝, 前田慎一郎, 藤田悦則, 金子成彦，榎園正人，棺田雄二，秋田昌憲，龟井勉，村 田幸治, 飲酒状態の非侵襲センシングシステム, 自動車 技術会春季学術講演会前刷集, №37-07, 15-18，2007.

(2) 高沢謙二: 加速度脈波による血管年齢の測定と臨床的有 用性. 第 38 回加速度脈波・脈波研究会講演予稿集, $2-7,2004$. 